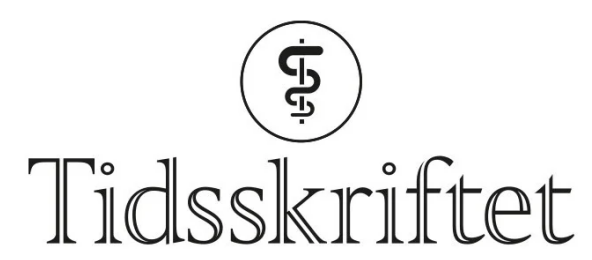

DEN NORSKE LEGEFORENING

\title{
Klar for endring?
}

\author{
ANMELDELSER
}

THOMAS MILDESTVEDT

Fastlege

Førsteamanuensis ved Faggruppe for allmennmedisin, Universitetet i Bergen

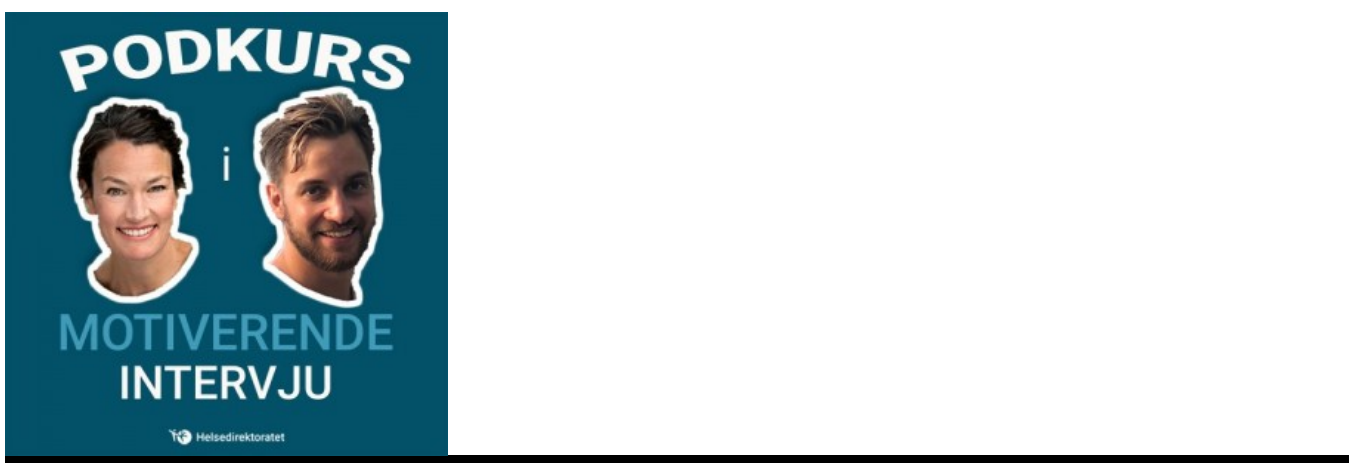

Podkurs i motiverende intervju

Helsedirektoratet, 2019

Podkasten tilbyr et lynkurs i samtalemetoden motiverende intervju (MI) i et format som særlig er egnet for den travle praktiker eller student som liker å få faglig påfyll i ledige stunder.

Kurset er utgitt av Helsedirektoratet, etter initiativ av en engasjert kollega, Herman Egenberg. Sammen med den erfarne gestaltterapeut og underviser av metoden, Solveig Høgh-Krohn ved Helsedirektoratet, utgjør de et dynamisk programlederpar. I fire episoder på 32-64 minutter tar de lytterne gjennom en introduksjon til MI. Metoden presenteres gjennom pasientsamtaler og rollespill som gir utgangspunkt for tilbakemeldinger og refleksjoner. Egenberg tar rollen som elev, slik at metoden presenteres gjennom refleksjon rundt hans egen endringsprosess og pasientsamtalene.

Podkurset har mål om at tilhøreren skal lære MI og samtaleteknikker. Det er nok en ambisiøs målsetting for en fire timers lytteøvelse. De skal likevel ha ros for å introdusere komplekse samtaleteknikker på en lettfattelig og inspirerende måte.

Vi blir mest motivert av oppmuntringer, aksept og fokus på det som går bra. Vi liker samtaler preget av vennlighet og respekt. Ved å fremme en god relasjon, modellerer podkurslederne holdninger fra MI og blir forbilder for oss som veiledere av pasienter eller 
studenter. Det som faktisk virker i MI, er ikke samtaleteknikkene alene, men veilederens holdninger til egen rolle, og pasientens eierskap til endringsprosessen er vel så viktig.

Tiltaksfasen i de fleste konsultasjoner inviterer pasientene til å gjøre endringer i eget liv. Selv det å ta en medisin, avlaste en skade, tilpasse aktiviteter eller komme til avtalt oppfølging krever tilpasninger som pasientene ofte ikke klarer å iverksette i sine liv. Leger må ta med mulighet for å gjennomføre tiltak sammen med behandlingsplanen.

Podkurset passer for alle som skal samtale med pasienter og klienter om endring, og som har behov for å snakke med noen om å få til en endring. Jeg kan vanskelig se for meg noen som ikke vil kunne ha nytte av å lære mer om disse prinsippene for å hjelpe mennesker til å ta ansvar for egen endring. Podkurset egner seg godt som pensum i grunnutdannelsen og for de fleste spesialiteter. Dersom dette kan knyttes til veiledede øvelser, vil læringseffekten bli stor.

Anmelder bidrar i utviklingen av et e-lceringskurs i livsstilsarbeid for Legeforeningen med fokus på kost og mosjon. Dette kurset vil bruke Podkurset som pensum med en praktisk kursdel med øvelser $i$ motivasjonssamtaler.

Publisert: 4. mai 2020. Tidsskr Nor Legeforen. DOI:10.4045/tidsskr.20.0174

(C) Tidsskrift for Den norske legeforening 2023. Lastet ned fra tidsskriftet.no 26. april 2023. 